\title{
An Integrated Framework to Analyze Local Decision Making and Adaptation to Sea Level Rise in Coastal Regions in Selsey (UK), Broward County (USA), and Santos (Brazil)
}

\author{
J. Marengo1, F. Muller-Karger ${ }^{2}$, M. Pelling3, C. J. Reynolds' ${ }^{2}$, S. B. Merrill4, L. H. Nunes ${ }^{5}$, \\ S. Paterson', A. J. Gray", J. T. Lockman7, J. Kartez ${ }^{8}$, F. A. Moreira ${ }^{5}$, R. Greco5 ${ }^{5}$, J. Harari ${ }^{9}$, \\ C. R. G. Souza ${ }^{10}$, L. M. Alves ${ }^{11}$, E. K. Hosokawa ${ }^{12}$, E. K. Tabuchi13
}

${ }^{1}$ National Center for Monitoring and Early Warning of Natural Disasters (CEMADEN), Sao Paulo, Brazil

${ }^{2}$ College of Marine Science, University of South Florida, St. Petersburg, FL, USA

${ }^{3}$ Department of Geography, King's College London, London, UK

${ }^{4}$ GEI Consultants Inc., Portland, ME, USA

${ }^{5}$ Institute of Geosciences, University of Campinas, Campinas, Sao Paulo, Brazil

${ }^{6}$ Future Earth Coast, MaREI Cente, Environmental Research Institute, University College Cork, Cork, Ireland

${ }^{7}$ GEI Consultants Inc., Montclair, New Jersey, USA

${ }^{8} \mathrm{New}$ England Environmental Finance Center, University of Southern Maine, ME, USA

${ }^{9}$ Institute of Oceanography, University of Sao Paulo, Sao Paulo, Brazil

${ }^{10}$ Geological Institute of São Paulo, Sao Paulo, Brazil

${ }^{11}$ Earth System Science Center, National Institute for Space Research, Sao Jose dos Campos, Sao Paulo, Brazil

${ }^{12}$ Secretary of Urban Development, Municipality of Santos, Santos, Sao Paulo, Brazil

${ }^{13}$ Secretary of Environment, Municipality of Santos, Santos, Sao Paulo, Brazil

Email: jose.marengo@cemaden.gov.br

How to cite this paper: Marengo, J., Muller-Karger, F., Pelling, M., Reynolds, C.J., Merrill, S.B., Nunes, L.H., Paterson, S., Gray, A.J., Lockman, J.T., Kartez, J., Moreira, F.A., Greco, R., Harari, J., Souza, C.R.G., Alves, L.M., Hosokawa, E.K. and Tabuchi, E.K. (2017) An Integrated Framework to Analyze Local Decision Making and Adaptation to Sea Level Rise in Coastal Regions in Selsey (UK), Broward County (USA), and Santos (Brazil). American Journal of Climate Change, 6, 403-424.

https://doi.org/10.4236/ajcc.2017.62021

Received: March 23, 2017

Accepted: June 25, 2017

Published: June 28, 2017

\begin{abstract}
One of the clear signals of the ongoing climate change is sea level rise (SLR). Normal oceanic tides superimposed on a rising sea level and coastal flooding will affect many coastal communities. An international collaboration among Brazil, the United Kingdom, and the United States was designed to evaluate local decision making processes and to open space for local urban managers to reflect on possible actions toward adaption to sea level rise given the historical constraints imposed by administrative and institutional structures. This project focused on the processes that shape adaptation of three coastal communities in three countries. It worked jointly with these communities in defining the problem, examining risks, and understanding the benefits and obstacles that may hinder implementation of adaptation options. The framework was co-designed by an interdisciplinary team that incorporated social and natural scientists from the three countries, including local government
\end{abstract}


Copyright (C) 2017 by authors and Scientific Research Publishing Inc. This work is licensed under the Creative Commons Attribution International License (CC BY 4.0).

http://creativecommons.org/licenses/by/4.0/ officials. The study addressed 1) evaluation of adaptive capacity through participant surveys and 2) physical and cost impact simulations using geospatial models of the built infrastructure and implementation of adaptation options under different hazard scenarios, including 50 and 100-year sea level rise projections and severe storms. Based on the surveys' results, there is a clear sense of the awareness of each community of the risk of floods due to intense storms, and of the usefulness of engaging early in a process that promotes the understanding of risks, impacts, and costs. A majority of workshop participants prioritized pursuing physical and green infrastructure actions now or within coming years or decades. A positive common aspect of the three sites was the commitment shown by the stakeholders in taking part in the process and evaluating which adaptation measures could be more effective in their cities. While in the US and UK structural solutions and voluntary buyouts were prioritized for the future, Brazil prioritized structural solutions and ecosystems restoration and not voluntary buyouts. All of these are choices to increase resiliency against sea level rise that have a high benefit-cost ratio. The Adaptive Capacity Index (ACI) results illustrate barriers to adaptation action, including technical, economic and political issues that reveal inequalities in adaptive capacity among case studies.

\section{Keywords}

Sea Level Rise, Vulnerability, Adaptation, Impacts, Climate Change

\section{Introduction}

Coastal areas of the world continue to show a faster rate of population growth than inland continental settings [1]. Coastal communities in low-lying geographic settings are especially vulnerable to hazards related to continuing sea level rise (SLR) and superimposed tidal variations and storm surges. Nearly $7 \%$ of human communities are in areas where elevation is less than 5 meters from historical sea level [2]. Most of the world's 60 million poor that live in low elevation areas reside in just 15 countries, including Brazil, the United States of America (USA) and the United Kingdom (UK) [3] [4]. Of these, approximately 40 million are exposed to major flood risks, and these risks are expected to increase over the next 50 years.

Severe flooding hazards are expected to increase along trailing edge of tectonic plates where there are a larger number of low-lying areas compared to more scattered areas on active tectonic margins. Along the Atlantic coasts of Central and South America, SLR between 1950 and 2008 has ranged from about 2 to 7 $\mathrm{mm} \cdot \mathrm{yr}^{-1}[5]$. Extreme coastal flooding events are becoming more frequent, with impacts on coastal urban areas and changing patterns of coastal erosion. A gradual increase in average sea level of $1 \mathrm{~m}$, often cited as a possible scenario within a 100-year timeframe [6] [7], would seriously affect some coastal populations in Brazil [8], the USA, and the UK [9] [10]. Damages are compounded when tidal fluctuations and surges due to severe storms are superimposed on these esti- 
mates.

Recent studies on climate adaptation enhance the importance of engaging or activating communities and supporting community roles in understanding climate change and adaptation needs [11]. Responses from cities to improve their resilience are urgent but policymakers need to understand current adaptation to plan comprehensively and spend effectively [12].

To evaluate how local government may respond to risks associated with SLR projections, a group of natural and social scientists from the USA, UK, and Brazil developed the METROPOLE project. METROPOLE is an effort to develop an integrated framework to analyze local decision-making and the adaptive capacity of communities facing environmental change.

The hypothesis of the METROPOLE team was that risk knowledge is best understood when it is co-produced with science and within social, political and cultural contexts. We analyze social context factors that affect adaptation planning and policy changes (adaptive capacity) and responses by local stakeholders when presented with interactive computer-based scenario simulations of SLR and impacts in participatory planning meetings. This study summarizes the results of efforts to evaluate local decision making processes concerning possible actions toward adaption to SLR and storm surge in communities in the UK, US and Brazil.

\section{Case Studies}

The METROPOLE team sought an initial understanding of residents' perception of coastal vulnerability associated with climate change risks and adaptation capacity in different communities with different social, political, and cultural contexts. A range of potential threats associated with SLR was evaluated by use of the Adaptive Capacity Index ACI [13] [14], which provided a comprehensive assessment of resilience at the level of government organizations by means of working with the community, including representatives of the public and private sectors. The evaluation developed case studies in three coastal areas: the city of Selsey (Chichester in West Sussex, UK), Broward County (Florida, USA), and Santos (São Paulo, Brazil). In this report we discuss how each community evaluated the potential benefits of adaptation, given scenarios of projected hazards, and compare the results obtained in these different areas.

Selsey is a seaside town and civil parish, about eight miles $(12 \mathrm{~km})$ south of Chichester, in the Chichester District of West Sussex, within the historic county of Sussex, England. Selsey lies at the southernmost point of the Manhood Peninsula or the English Channel with a population estimated in 2015 of 11,141. The town's main socio-economic driver is tourism, with extensive physical infrastructure in place to accommodate major seasonal visitation patterns. Due in part to transport access issues, limited to one major road, a large industrial sector has not developed in Selsey. Coastal erosion has been an ever-present problem for Selsey and prior to the construction of sea defences in 1956, the Selsey peninsula was one of the most rapidly eroding shorelines in the UK. 
Broward County is located on the southeastern coast of the USA, in the state of Florida. The 2010 Census estimated the population at 1,748,066, making it the second-most populous county in Florida. Broward County's tourism and industrial activities benefit from critical infrastructure such as Port Everglades and the Fort Lauderdale-Hollywood Airport. Broward County has an average elevation of only $1.8 \mathrm{~m}$ above sea level, and is considered one of the areas in the United States most vulnerable to an increase in sea level. Indeed, most of Southeast Florida is at high risk of flooding, contamination of ground water, and loss of coastal and wetland habitat due to sea level rises.

Santos is a coastal city in the State of Sao Paulo in southeastern Brazil. Santos and areas adjacent to the city are a strategic economic center for Brazil, with a large concentration of industries located along the coastal zone. The Port of Santos, the key economic asset for the municipality of Santos, is responsible for the transport of products from the largest industrial park in Brazil and handles some $25 \%$ of Brazil's foreign trade. Santos is a portrait of the social contrasts of the country, featuring upscale neighborhoods, especially near the oceanfront [15]. Over $99 \%$ of the population of Santos (433,359, estimated in 2016) lives in the insular domain of the city.

The three study sites present both similarities (coastal cities threatened by the risk of sea-level rise) and differences (the size of the population and of the local economy), which make the comparison of the attitudes and values about local climate risks and adaptation strategies among decision-makers and stakeholders particularly challenging.

\section{Methods}

To help stakeholders in each community to assess risk due to several SLR scenarios, develop adaptation options and evaluate possible decisions on these options, we used a participatory approach. Communities learned about the possible risks and impacts through two workshops: one helped assess the economic impacts of SLR in each of the three locations, and explored possible strategies that each municipality might use to minimize damage and costs. The second workshop analyzed the different factors that hindered or facilitated the implementation by the community and its organizations of the various adaptation options, providing greater clarity on possible actions. The two workshops were held in each of the three cities and were organized by the scientific community of METROPOLE, together with the city councils in each case. Among the participants were the academics policy decision makers, civil society, NGOs and the population in general, as well as military and civil defense people.

\subsection{Surveys}

Prior to each workshop, the METROPOLE team distributed a survey intended to evaluate the knowledge, values, as well as the disposition of the participants to the process of community change in facing risk and costs, associated with climate change. The surveys helped to compare social, demographic and political 
aspects of the different communities and how these might affect decisions on adaptation options. The information derived from the surveys is shared with community leaders. While the first survey is dedicated to gaining an understanding of perceptions about hazards and preferences among adaptation options and funding sources in different communities, the second survey is more directed towards an understanding of local perceptions of coastal hazards and preferences for how to develop adaptation actions.

The same questionnaires were used in the three case studies and in Santos they were translated into Portuguese and somewhat adjusted to the local realities. The main questions of the surveys included: population's experiences with hazards, questions about potential adaptation actions, questions about possible funding sources by local governments, perspectives about adaptation and environment and some questions about demographics of the participants. The analysis of results for each case study and intercomparisons are a matter of ongoing studies.

\subsection{Adaptive Capacity Index (ACI)}

Understanding the standards and base values of organizations playing a key role in climate change adaptation provides insight into how priorities are being set and what shifts in approach may be possible.

In this study, the adaptive capacity was evaluated through the ACI approach [16]. ACI is designed to measure and interpret institutional architecture and the flexibility of individuals that shape adaptive capacity and is derived from well-prepared face-to-face interviews. The ACI methodology has three components: 1) the index-a quantitative expression of adaptive capacity; 2) policy review, and 3), a learning tool-respondent can use the conversation through which the tool is delivered to reflect on current practice, goals and procedures. These components combined the objectivity suggested by an index, with a more nuanced analysis of policy options. The complementary components are designed to help move the adaptive capacity of the organizational landscape in a desired direction while providing an opportunity for participants to consider an organizational capacity for change [17].

The ACI provides a mechanism through which existing management priorities; organizational structures and governance can be reviewed at multiple scales with a view to identifying efficient pathways for mainstreaming adaptation. The process enabled local decision-makers and sector representatives to share experiences, insights and expected difficulties that may hinder efforts. The degree of adaptive capacity of the system depends on how a series of strategies, capabilities and available assets interact within a dynamic context to allow individuals, households, communities, organizations and institutions to cope with changes to their environment.

The ACI model has various subcomponents that form the underlying conceptual framework for the survey instrument: levels of capital (social and human, technological and economic); organization architecture, organizational re- 
sponsibility, ability to experiment, ability to learn, command over available resources, ability to plan for the future and critical self-reflection. In the surveys these subcomponents are divided into four main sections: 1) Risk Identification; 2) Risk Reduction; 3) Learning and 4) Adaptive Governance.

Sample frames were derived from decision-making organizations with responsibilities for short and long-lasting, potentially climate-impacted decisions and also from framework organizations whose actions set the frame for adaptive actions by a wider range of organizations. Organizations across government agencies, civil society and private entities throughout the landscape of sectors, including land use/planning/management, environment, emergency and risk management, transport, energy and water, economy, social structure and health were approached at each site.

To enhance the potential insight into adaptation practices, respondents were asked to comment on present-day organizational capacities, along with capacities at two previous times, in order to generate a trajectory over time. In the case of this study the two additional time points used were 2005 and 2010 (in addition to 2015) due to political events such as national elections and/or disaster events such as flooding and landslides impacting each site. During the interviews respondents assigned a value for performance on a five-point scale for each index indicator and were asked to provide examples of input and outputs for each indicator to help justify their assessment of performance. The five-point scale (Very limited, Basic, Appreciable, Outstanding and Optimal) was assigned a textual descriptor and in analysis a numerical value of 1 (Very limited) to 5 (Optimal).

Results were evaluated in both quantitative and qualitative ways: the former produces a description of capacity from the viewpoint of respondents and can be presented for each respondent and in aggregate form. Interview data were also analyzed and coded qualitatively to draw out processes, gaps and opportunities to help improve analytical clarity and focus policy recommendations.

\subsection{SLR and COAST Modeling}

The team used the COastal Adaptation to Sea Level Rise Tool (COAST) developed by [18] and the first challenge was to find the appropriate input data at each location to make the risk and impact simulations. Risks and the associated costs were estimated using the COAST platform [19] [20] [21]. COAST estimates SLR and storm surge impacts, by calculating damage from storm surge events cumulatively over time, given a changing base water level. It then calculates relative benefits of various adaptation scenarios in terms of cumulative avoided damages over time. The model is designed to provide information to municipalities, state agencies and other groups interested in benefit-cost analysis for adaptation strategies aimed at reducing damages from SLR and storm surge. COAST created data visualizations of coastal change based on SLR and superimposed storm surge events, to help users understand economic and environmental consequences of flooding scenarios. 
COAST requires input on the time horizons to be simulated (e.g., 30, 100 years), projected SLR curves, vulnerable assets such as infrastructure including real estate and values per square meter and the types of actions that a community would take (moving and rebuilding on higher ground, fortification such as seawalls, etc.). COAST computed financial impacts using inputs from local stakeholders and engineers.

Different SLR curves and estimates of extreme flood heights and the time horizon for evaluating impacts at each location were selected by each of the communities as provided by local authorities and regional studies [9] [10] [22]. The observed sea level is a composite of tide and surge, the former being due to astronomical effects and the latter due to meteorological influence. The tides are predictable, but predictions of surges are more difficult and usually depend on precise meteorological predictions and on the time scale of interest. Large-scale climatological variations induce large-scale variations in the ocean, which are referred to as sea level variations, the most important being the sea level rise, due to its inherent risks to coastal populations. As consequence of surges and longterm sea level elevation, coastal areas are subject to flooding, which may be temporary (associated to intense surges) or quasi-permanent (in the case of a consistent sea level rise). Table 1 shows surge heights and expected real estate damage under low and high SLR scenarios for the mid (2055, 2030 and 2050) and long term $(2085,2060$ and 2100$)$ for the three case studies.

Table 1. Surge heights and expected real estate damage under low and high SLR scenarios in the three study countries, for the mid (2055, 2030 and 2050) and long term (2085, 2060 and 2100)

\begin{tabular}{|c|c|c|c|c|c|c|c|c|}
\hline \multicolumn{3}{|c|}{ Selsey, UK* } & \multicolumn{3}{|c|}{ Broward County, US** } & \multicolumn{3}{|c|}{ Santos, Brazil $1^{\star * *}$} \\
\hline Year & Scenario & Scenario & Year & Scenario & Scenario & Year & Scenario & Scenario \\
\hline & Low & High & & Low & High & & Low & High \\
\hline 2055 & & & 2030 & & & 2050 & & \\
\hline $\operatorname{SLR}(\mathrm{m})$ & 0.32 & 0.36 & $\operatorname{SLR}(\mathrm{m})$ & 0.08 & 0.18 & $\operatorname{SLR}(\mathrm{m})$ & 0.18 & 0.23 \\
\hline $\begin{array}{l}\text { Surge height } \\
\text { above } \text { MHHW }^{+} \text {, } \\
\text { with SLR }(\mathrm{m})\end{array}$ & 2.35 & 2.39 & $\begin{array}{l}\text { Surge height above } \\
\text { MHHW, with SLR } \\
\text { (m) }\end{array}$ & 1.90 & 2.01 & $\begin{array}{l}\text { Surge height } \\
\text { above MHHW, } \\
\text { with SLR (m) }\end{array}$ & 1.33 & 1.38 \\
\hline $\begin{array}{l}\text { One time cost } \\
\text { (million USD) }\end{array}$ & 24 & 26 & $\begin{array}{l}\text { One time cost } \\
\text { (million USD) }\end{array}$ & 452 & 518 & $\begin{array}{l}\text { One time cost } \\
\text { (million USD) }\end{array}$ & 34 & 38 \\
\hline 2085 & & & 2060 & & & 2100 & & \\
\hline $\operatorname{SLR}(\mathrm{m})$ & 0.68 & 0.75 & $\operatorname{SLR}(\mathrm{m})$ & 0.23 & 0.61 & $\operatorname{SLR}(\mathrm{m})$ & 0.36 & 0.45 \\
\hline $\begin{array}{l}\text { Surge height } \\
\text { above } \text { MHHW }^{+} \text {, } \\
\text { with SLR (m) }\end{array}$ & 2.71 & 2.78 & $\begin{array}{l}\text { Surge height above } \\
\text { MHHW, with SLR } \\
\text { (m) }\end{array}$ & 2.06 & 2.44 & $\begin{array}{l}\text { Surge height } \\
\text { above MHHW, } \\
\text { with SLR (m) }\end{array}$ & 1.51 & 1.6 \\
\hline $\begin{array}{l}\text { One time cost } \\
\text { (million USD) }\end{array}$ & 42.3 & 46.4 & $\begin{array}{l}\text { One time cost } \\
\text { (million USD) }\end{array}$ & 629.7 & 862.7 & $\begin{array}{l}\text { One time cost } \\
\text { (million USD) }\end{array}$ & 60.5 & 74.8 \\
\hline $\begin{array}{l}\text { Cumulative } \\
\text { damages } \\
\text { (million USD) }\end{array}$ & NC & NC & $\begin{array}{l}\text { Cumulative } \\
\text { damages } \\
\text { 2015-2060 } \\
\text { (million USD) }\end{array}$ & 3348 & 5257 & $\begin{array}{l}\text { Cumulative } \\
\text { damages } \\
\text { 2010-2100 } \\
\text { (million USD) }\end{array}$ & 242 & 290 \\
\hline
\end{tabular}

${ }^{*}$ ) Scenarios for a 200-year flood with SLR. $\left(^{* *}\right)$ Scenarios for a Hurricane Wilma-sized flood with SLR. ${ }^{* * *}$ Scenarios for a 100-year flood with SLR for Southeast Santos. (NC) Not calculated. $\left(^{+}\right)$MHHW-Mean Higher High Water. 
The COAST model incorporates a database containing the following parameters describing local conditions: 1) sea level rate of rise based on historical tide gauge records and satellite altimetry; 2) Digital Elevation Model (DEM) from LiDAR; 3) elevation of mean high tide, where the model adds sea level rise and storm surge to a mean high water height; 4) surge height, with probabilities and surge heights (water levels above high tide) for the 500-year, 100-year, 50-year and 10-year storm events; 5) flood maps, representing the spatial extent of the area of flooding that has a $1 \%$ chance of occurring; 6) digital tax parcel map, considering value of buildings/tax assessment values of buildings; and 7) depth damage function (DDF), which indicates the predicted percent loss to the value of a building, based upon the flood depth at its base, with damage functions for different structure types (such as residential or commercial; properties with or without basement, etc.). LiDAR maps and digital terrain models are data needed to evaluate the degree of seawater flooding as sea level rises in the future, or as floods occur. These digital elevation models are required for the COAST model.

Data from Santos were collected from the Muncipality of Santos Database and from different municipality departments, such as Finance, Urban Development, Environment and Civil Defense Secretaries, including recent LiDAR data [22]. Hourly sea level observations from the tide gauge data of Torre Grande (Santos), $23^{\circ} 56^{\prime} 95^{\prime \prime} \mathrm{S} 46^{\circ} 18^{\prime} 50^{\prime \prime} \mathrm{W}$, for the period from 1945 to 1990 and multi-satellite altimetric dynamic topography at the position $23.875^{\circ} \mathrm{S} 46.375^{\circ} \mathrm{W}$, from $1993-$ 2014 were used for SLR measurements. Two processes were modeled: the sea level trend (using both sets of data) and the expected maximum for return periods of 50 and 100 years (using the tide gauge data only).

Data for Broward County were obtained from different sources [9]: DEM maps come from [23], Mean Higher High Water (MHHW) from the NOAA tide station at the Bahia Yacht Club in Ft. Lauderdale [24] was the base reference upon which storm surge and sea level rise were added; SLR curves (low and high) were used to calculate amounts of damage to buildings over time and come from a Unified Sea Level Rise Projection for Southeast Florida from 2011. Storm surge values that COAST used to determine inundation of parcels each year in the multi-decade scenarios for Broward County were derived from FEMA Flood Insurance Rate Maps (FIRMs) and Flood Insurance Study (FIS) reports. Parcel and building types were provided by the Broward County Property Appraiser Network and were then matched with depth-damage functions for building types outlined by [25] for the US Army Corps of Engineers. There are good digital elevation models for the area.

Data from Selsey, UK [10] DEM obtained by the [26], for Mean Higher High Water (MHHW) were the base reference upon which storm surge and sea level rise were added. Two years of recorded information was obtained from the Portsmouth, England tide gauge and used to calculate MHHW. There were no accurate land elevation models for Selsey, UK, and there was no LiDAR data for this locality. Therefore, because of the poor quality of the coastal topography data available, the COAST model could not compute cumulative-avoided dam- 
age over time. Two sea level rise curves (Low and High) were used to calculate damage to residential buildings. The low curve values were obtained from the North Solent Shoreline Management Plan, and the high curve values were obtained from the Strategic Flood Risk Assessment of Chichester District Council Volume II-Technical Report [27]. Storm surge values that COAST used to determine inundations of residential buildings were derived from the North Solent Shoreline Management Plan [28]. A list of residential properties with taxable values and their geographic locations was obtained from the Chichester District Council.

\subsection{Adaptation Scenarios for COAST Modeling}

In each case study, two scenarios were analyzed for mid and end of 21th Century SLR projections. One scenario evaluated vulnerability if "no action" is taken by the community and infrastructure remained as it is at present. Another scenario evaluated a range of adaptation measures proposed by local communities during the METROPOLE engagement workshops. To apply the COAST model for each community, we incorporated datasets from nationally or regional accepted sources (see Methods section).

Municipal contacts and local experts determined that the assessments needed to include SLR projections for low and high scenarios for particular timeframes. Each community chose target projection years defined by their own planning processes. Specifically, the communities of Broward County (USA) and Santos (Brazil) requested damage assessments for anticipated flood events for 2030 and 2060 for Broward County, for 2050 and 2100 in Santos, and 2055 and 2085 for Selsey. At each location, the decisions of stakeholders was shaped by their experience of either extreme or recurrent nuisance floods $(1.05 \mathrm{ft})$, including projected 100- and 200-year floods, or the flood associated with particular storms, such as Hurricane Wilma (6.0 ft) in the USA [9]. The community of Santos decided to focus on projections for 2050 and 2100 and a 100-year flood. In Selsey, the community considered one-time damages from a 200-year flood in 2055 and 2085 with low and high SLR scenarios. In Santos, hourly tide gauge data from Torre Grande were used to estimate the expected maximum for return periods of 50 and 100 years, by using the Gumbel distribution on the yearly mean values, giving the heights of $1.60 \mathrm{~m}$ in 2050 and $1.66 \mathrm{~m}$ in 2010, for an observed maximum of $1.45 \mathrm{~m}$ in the sampling period.

The "no action" scenario is a baseline vulnerability assessment that was used for comparing the costs and benefits from various adaptation options. Benefit (avoidable damage) is the difference between cost with and without adaptation. Adaptation strategies modelled in the three communities included fortification (modifying the flow of water by means such as seawalls, jetties, and dikes), accommodation (modifying the impact of water via floodproofing, elevating houses, etc.), and relocation (via voluntary buyouts, rolling easements, etc.).

The benefit-cost ratio is calculated as the relation between benefit and cost of adaptation measures. A ratio lower than 1 suggests that adaptation measures 
would cost more than the avoided damages for both SLR scenarios; ratios higher than 1 suggest that the economic damages would be smaller with adaptation options implemented. For Santos, Table 2 shows that the economic damages in this region would be, for high and low SLR scenarios, respectively, nearly 24 to 29 times smaller with adaptation than damages projected if no action were taken. Similarly, for Broward County, the costs would be nearly 22 to 31 times smaller with adaptation than damages projected if no action were taken.

Broward County chose a specific adaptation scenario that included flood proofing, elevating structures and voluntary buyouts to protect commercial and residential real estate and government structures. Selsey chose to model different types of seawalls and combinations of seawall heights to protect residential areas. Santos adopted dredging and mangrove restoration for its northwestern region, while for the Southeastern region reinforcement of existing walls and beach nourishment were the selected options.

Commercial buildings were not included in the list of properties. This represents an underestimate of risk and of damages. COAST also did not estimate damage from winds, erosion forces, or rainwater drainage backups, which might also cause building damage, substantially threaten health and other property, and changes local ocean circulation, salinity, etc., that may in turn also affect local sea level.

\section{Results}

\subsection{Sea Level Rise Impacts}

The METROPOLE team worked jointly with a set of stakeholders in each community to evaluate risks and impacts of SLR with the COAST tool and evaluate

Table 2. Cumulative damages without and with adaptation scenarios in the three study countries.

\begin{tabular}{cccccccc}
\hline \multicolumn{1}{c}{ Item } & \multicolumn{2}{c}{ Selsey, UK* } & \multicolumn{2}{c}{ Broward county, US** } & \multicolumn{2}{c}{ Santos, Brazil ${ }^{* * *}$} \\
\hline & Scenario & Scenario & Scenario & Scenario & Scenario & Scenario \\
\hline & Low & High & Low & High & Low & High \\
\hline $\begin{array}{c}\text { Cumulative damage without } \\
\text { adaptation (billions USD) }\end{array}$ & NC & NC & $\$ 3.348$ & $\$ 5.257$ & $\$ 0.242$ & $\$ 0.467$ \\
$\begin{array}{c}\text { Cumulative damage with } \\
\text { adaptation (billions USD) }\end{array}$ & NC & NC & $\$ 2.090$ & $\$ 4.466$ & 0 & 0 \\
$\begin{array}{c}\text { Avoided damages (benefit, } \\
\text { billions USD) }\end{array}$ & NC & NC & $\$ 1.258$ & $\$ 1.791$ & $\$ 0.242$ & $\$ 0.467$ \\
$\begin{array}{c}\text { Cost of adaptation measures } \\
\text { (millions USD) }\end{array}$ & NC & NC & $\$ 57.0$ & $\$ 116.0$ & $\$ 10.1$ & $\$ 10.1$ \\
\begin{tabular}{c} 
Benefit-cost ratio \\
\hline
\end{tabular} & NC & NC & 22.0 & 31.4 & 23.9 & 28.7 \\
\hline
\end{tabular}

${ }^{*}$ ) Scenarios for a 200-year flood with SLR, for 2015-2085, with fortification (improved seawall and embankment, but excluding new harbor breakwater and voluntary property buyouts). ( ${ }^{* *}$ ) Scenario for a Hurricane Wilma-sized flood with SLR, for 2015-2060, with elevation and flood proofing. ${ }^{* * *}$ ) Scenarios for a 100-year flood with SLR, for 2010-2100, with fortification (beach nourishment + dune restoration, structural enforcement/improvement of existing sea-walls) for Southeast Santos. NC Not calculated. 
the disposition of the community to change using the ACI [16]. The process used the participatory approach of Daniels and Walker [29] and [30] to explore the complex issue of how communities of different cultural backgrounds respond to risk.

\subsection{Adaptation Options Selected in the Three Case Studies}

The community was able to change the possible scenarios to be evaluated with the COAST model, and examined the outcome of different adaptation scenarios (i.e. benefit-cost analyses). Figures 1-3 show maps of each of the three cities, with storm surge flood extent and a graphical representation of the cost of damages. Each figure includes the impacts estimated for the medium- and long-term SLR scenarios and for particular flood events. Table 2 shows estimates of damages for the one-time events and the cumulative damages for the non-action scenario for the 100-year category flood events (Santos), and the Hurricane Wilma class flood (Broward County). Since there were no accurate land elevation models for Selsey, UK, the COAST model could not compute cumulative
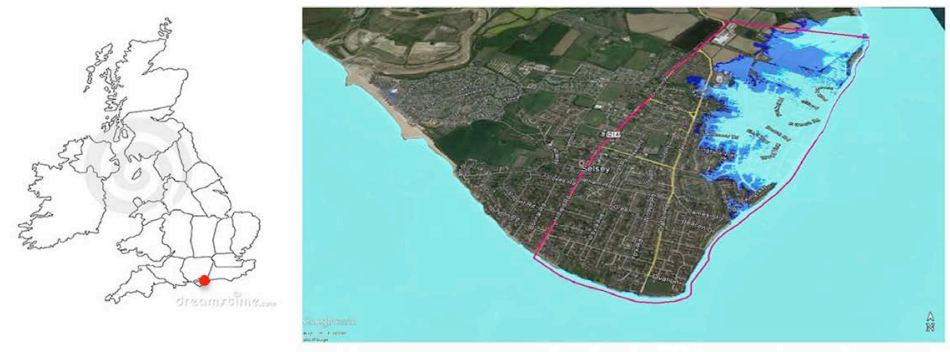

Flood Scenarios 2085 High SLR, 200yr Storm 2085 Low SLR, 200yr Storm 2055 High SLR, 200yr Storm 2055 Low SLR, 200yr Storm

Height of blue bars indicates level of structural damage to residential buildings, light blue shows the storm surge flood.

200-year Storm in 2055, with Low SLR $(0.32 \mathrm{~m})$

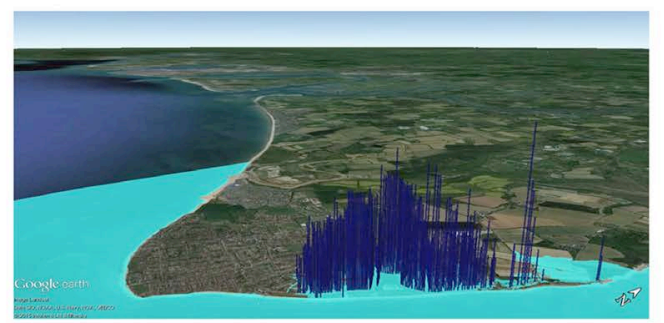

200-year Storm in 2055, with High SLR $(0.36 \mathrm{~m})$

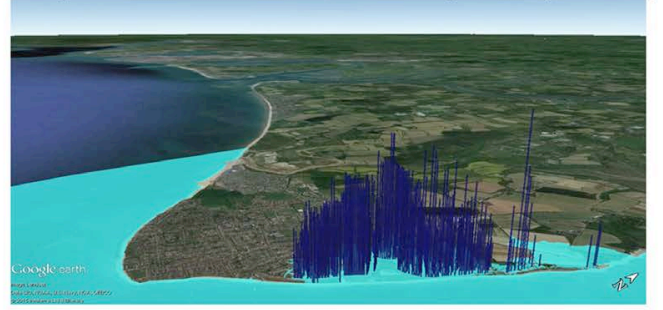

200-year Storm in 2085, with Low SLR $(0.68 \mathrm{~m})$

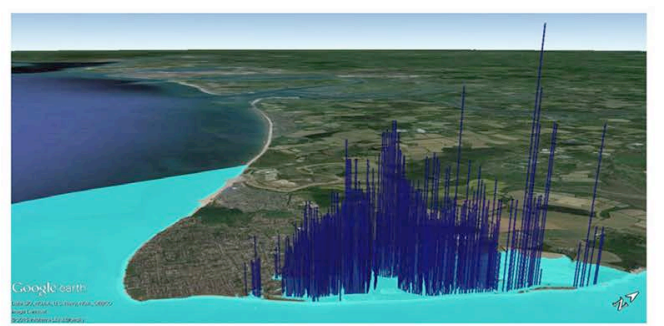

200-year Storm in 2085, with High SLR $(0.75 \mathrm{~m})$

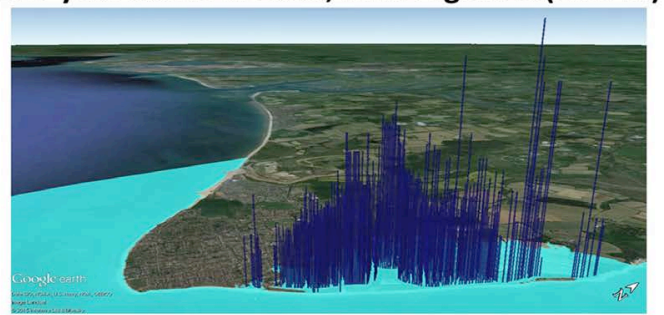

Figure 1. One-time storm surge flood and damage estimate for 200-year storm flood in 2055 and 2085 with low and high sea level rise scenarios for Selsey/UK. Height of blue bars indicates qualitatively the level of structural damage to residential buildings at each location; light blue shows storm surge. Location of the site is a red dot on the upper level map. 

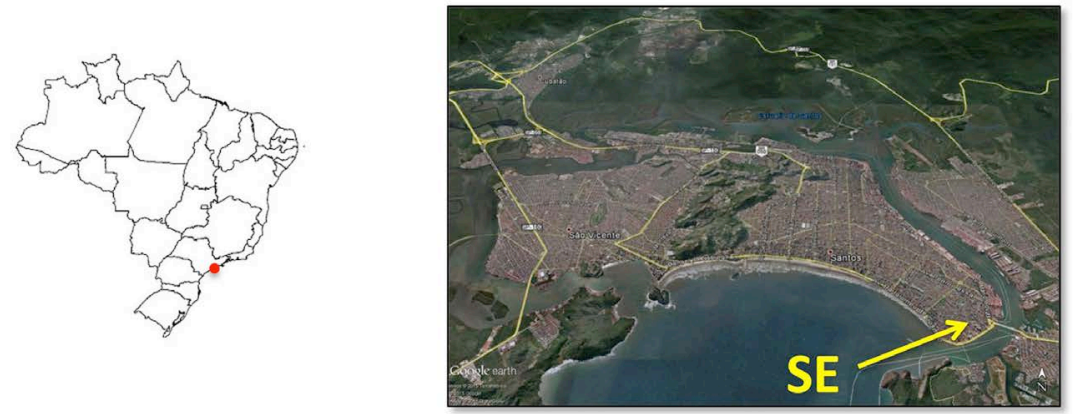

Height of blue bars indicates level of structural damage to residential buildings, light blue shows the storm surge flood.

100-year Storm in 2050, Low SLR (0.18 m)

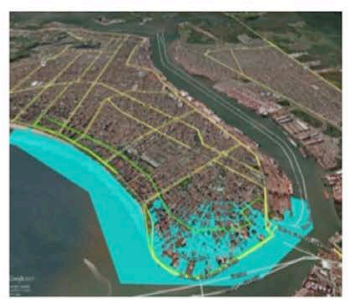

100-year Storm in 2050, High SLR $(0.23 \mathrm{~m})$

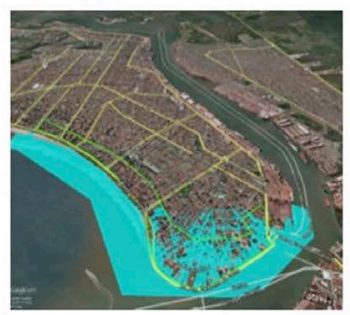

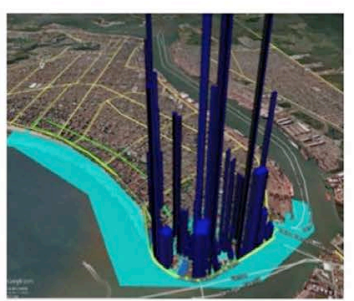

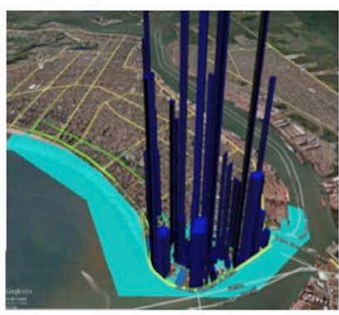

100-year Storm in 2100, Low SLR $(0.36 \mathrm{~m})$
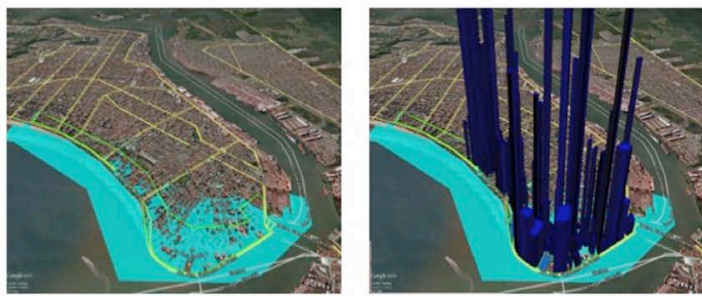

100-year Storm in 2100, High SLR $(0.45 \mathrm{~m})$
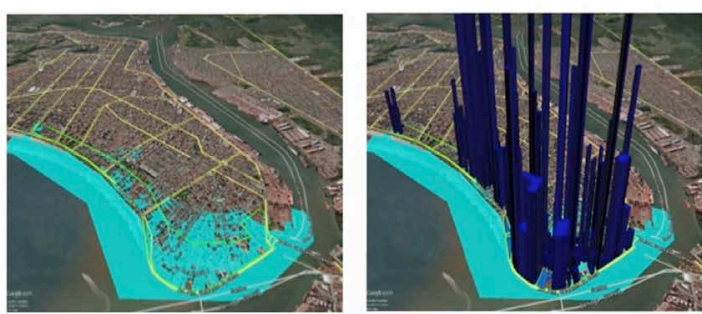

Figure 2. One-time storm surge flood and damage estimate for 100-year storm flood in 2050 and 2100 with low and high sea level rise scenarios for southeast Santos, Brazil. Height of blue bars indicates level of structural damage to residential buildings; light blue shows storm surge. Location of the site is red dot on the upper level map.

avoided damage over time. Floods clearly have more intense impacts over the long-term horizon at the three locations. SLR alone showed minimal to no flooding impacts in the modeled scenarios (data not shown).

Selsey chose to model different types of seawalls and combinations of seawall heights to protect residential areas. Selsey currently has a substantial seawall, but no coastal topographic maps were available to input into the COAST model. Thus, the community decided only to evaluate the impacts of a 200-year storm, for which the assumption was that the existing seawall would not contain the flood. A 200-year flood in 2085 under low and high SLR scenarios would have impacts of order of US $\$ 42$ and US $\$ 46$ million, respectively (Table 2). As indicated in the methods section, it was not possible to compute cumulative benefit-cost ratios for Selsey because of the lack of accurate topographic maps or a digital elevation model.

Broward County chose a specific adaptation scenario that included floodproofing, elevating structures, and voluntary buyouts to protect commercial and residential real estate and government structures. Elevating houses and floodproofing the coastline were among the choices, and were selected because they 

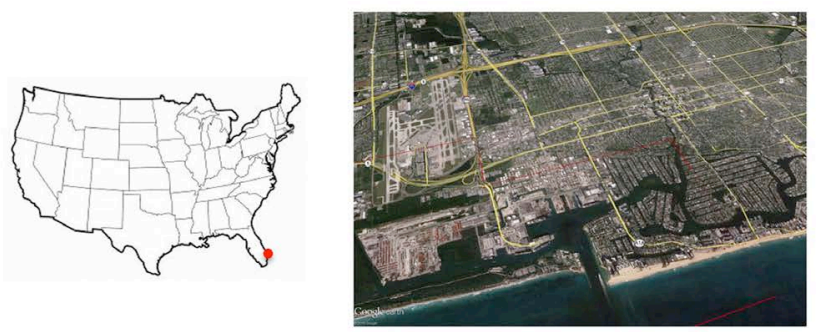

Flood Scenarios

2060 High SLR, Wilma-sized Storm

2060 Low SLR, Wilma-sized Storm

2030 High SLR, Wilma-sized Storm

2030 Low SLR, Wilma-sized Storm

Height of blue bars indicates level of structural damage to residential buildings, light blue shows the storm surge flood.

Hurricane Wilma-sized Storm in 2030, Low SLR (0.08 m) Hurricane Wilma-sized Storm in 2060, Low SLR (0.23 m)
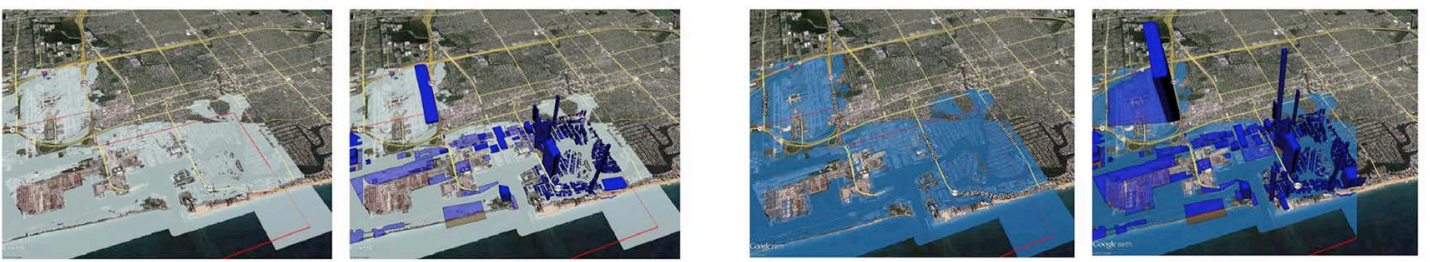

Hurricane Wilma-sized Storm in 2030, High SLR $(0.18 \mathrm{~m})$

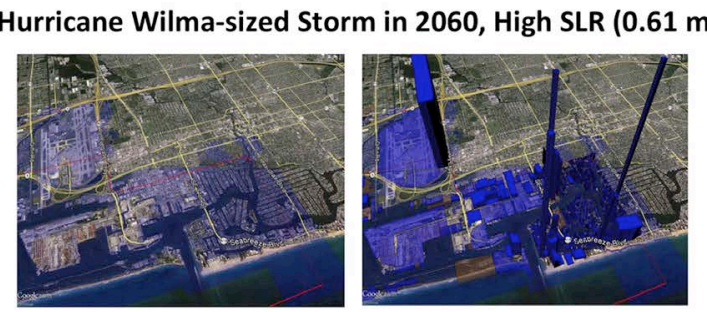

Figure 3. One-time storm surge flood and damage estimate for Hurricane Wilma-size flood in 2030 and 2060 with low and high sea level rise scenarios for Broward county/USA. Height of blue bars indicates level of structural damage to commercial and residential buildings; light blue shows storm surge. Location of the site is a red dot on the upper level map.

were more cost-effective. Without any adaptation actions, the COAST tool provided rough baseline estimates of the cost of damage from major floods superimposed on projected sea level. For example, flood damages from a Hurricane Wilma-class storm in Broward County, USA, in 2030, under low SLR scenario, were estimated as over US $\$ 452$ million (Table 2). In a high SLR scenario the costs would rise to US $\$ 518$ million. By 2060, such damages under low and high SLR scenarios could approach US $\$ 620$ million and US $\$ 860$ million, respectively.

Selsey chose to model different types of seawalls and combinations of seawall heights to protect residential areas. Selsey currently has a substantial seawall, but no coastal topographic maps were available to input into the COAST model. Thus, the community decided only to evaluate the impacts of a 200 -year storm, for which the assumption was that the existing seawall would not contain the flood. A 200-year flood in 2085 under low and high SLR scenarios would have impacts of order of US $\$ 42$ and US $\$ 46$ million, respectively (Table 2). As indicated in the methods section, it was not possible to compute cumulative benefit-cost ratios for Selsey because of the lack of accurate topographic maps or a digital elevation model.

Santos adopted dredging and mangrove restoration for the northwestern sec- 
tor, while for the southeastern sector reinforcement of existing walls and beach nourishment were the selected options. The community evaluated beach nourishment, dune restoration, structural enforcement of existing sea-walls, water pumping and improvement of tide control gates in existing drainage canals. In the southeastern sector of the city the damages from a 100-year flood in 2050 under low and high SLR scenarios would be US $\$ 34$ and US \$38 million, while in 2100 these damages could reach US $\$ 60$ and US $\$ 75$ million, respectively (Table 2).

Adaptation strategies chosen for planning were different in each of the three communities. In all cases, estimated costs and projected real estate losses were lower if particular adaptation actions were chosen compared to no-action scenarios. Table 2 provides benefit-cost results for adaptation strategies in each community. For the elevation and flood proofing strategy in Broward County, there were US $\$ 1.258$ billion in avoided damages under the low SLR scenario, and US $\$ 1.791$ billion in avoided damages for high SLR. The benefit-cost ratios ranged from 22.0 (low SLR) to 31.41 (high SLR). Strategies with ratios greater than 1 were considered cost-effective. These represent long-term savings in the form of damage reduction for every dollar spent today. For example, every US $\$ 1.00$ spent today to elevate and flood proof buildings could save US $\$ 31.41$ by 2060 in Broward County. These estimates do not include inflation.

The cumulative benefit (avoided damage) in Santos for the 100-year flood for 2010-2100 was US \$242 million for the low SLR projection, and US \$467 million for the high SLR scenario. In Santos, benefit-cost ratios ranged from 23.9 to 28.7 for the low and high SLR scenarios. For the high SLR scenario, every US $\$ 1.00$ spent today in fortification was estimated to save US $\$ 28.70$ by 2100 .

\subsection{ACI Analysis}

Evaluating the ACI is an analytical process that engages a range of stakeholders in a comprehensive and thoughtful assessment of community resilience and ability to proactively seek change. The METROPOLE Project focused the ACI assessment on key actor organizations within the environmental risk scene. Respondents commented on contemporary capacities for the 2015 timeframe and for two others (2005 and 2010), in order to develop a trend analysis and compare current and historical shifts in adaptive capacity.

Developing the ACI required conducting surveys. The METROPOLE team specialists conducted 23 interviews in Broward County, 19 in Selsey and 24 in Santos. The interviewees included a broad cross-section of government, civil, and private sector actors, representative institutions and organizations active in evaluating risk scenarios in Selsey, Broward County and Santos.

Table 3 and Figures 4-6 present the overall ACI scores for Selsey, Broward County and Santos evaluated over the 2005-2015 decade. The results demonstrate general variability with some subcomponents showing limited variation over time, with some factors increasing and others decreasing over the decade under examination. The community's response was to attribute any trends to 
Table 3. Overall adaptive capacity index (ACI) sub-components scores for Selsey, UK, Broward county, US and Santos, Brazil.

\begin{tabular}{|c|c|c|c|c|c|c|c|c|c|}
\hline \multirow{2}{*}{ Subcomponents } & \multicolumn{3}{|c|}{ Selsey, UK } & \multicolumn{3}{|c|}{ Broward county, US } & \multicolumn{3}{|c|}{ Santos, Brazil } \\
\hline & 2005 & 2010 & 2015 & 2005 & 2010 & 2015 & 2005 & 2010 & 2015 \\
\hline $\begin{array}{c}\text { Critical } \\
\text { self-reflection }\end{array}$ & 2.00 & 2.13 & 2.25 & 2.62 & 2.89 & 3.18 & 3.03 & 3.14 & 3.41 \\
\hline $\begin{array}{c}\text { Ability to } \\
\text { experiment }\end{array}$ & 2.92 & 2.92 & 3.00 & 2.66 & 3.08 & 3.55 & 2.69 & 2.69 & 2.94 \\
\hline Ability to learn & 1.92 & 2.46 & 2.58 & 2.16 & 2.70 & 3.08 & 2.91 & 3.12 & 3.41 \\
\hline $\begin{array}{l}\text { Ability to plan } \\
\text { for the future }\end{array}$ & 2.52 & 2.83 & 2.96 & 2.33 & 2.90 & 3.33 & 2.99 & 3.17 & 3.43 \\
\hline $\begin{array}{c}\text { Command } \\
\text { over available } \\
\text { resources }\end{array}$ & 2.09 & 2.09 & 1.97 & 2.39 & 2.76 & 3.05 & 2.37 & 2.59 & 3.01 \\
\hline $\begin{array}{l}\text { Organizational } \\
\text { responsibility }\end{array}$ & 2.03 & 2.47 & 2.63 & 2.26 & 2.60 & 3.16 & 3.11 & 3.33 & 3.61 \\
\hline $\begin{array}{c}\text { Organizational } \\
\text { architecture }\end{array}$ & 2.68 & 2.93 & 3.03 & 2.33 & 2.72 & 3.21 & 2.77 & 2.91 & 3.18 \\
\hline Levels of capital & 2.97 & 2.84 & 2.65 & 2.61 & 2.81 & 3.18 & 2.99 & 3.19 & 3.40 \\
\hline & 19.13 & 20.67 & 21.07 & 19.36 & 22.46 & 25.74 & 22.86 & 24.14 & 26.39 \\
\hline
\end{tabular}

Adaptive Capacity Index (ACI) Sub-Components Scores: Selsey, UK

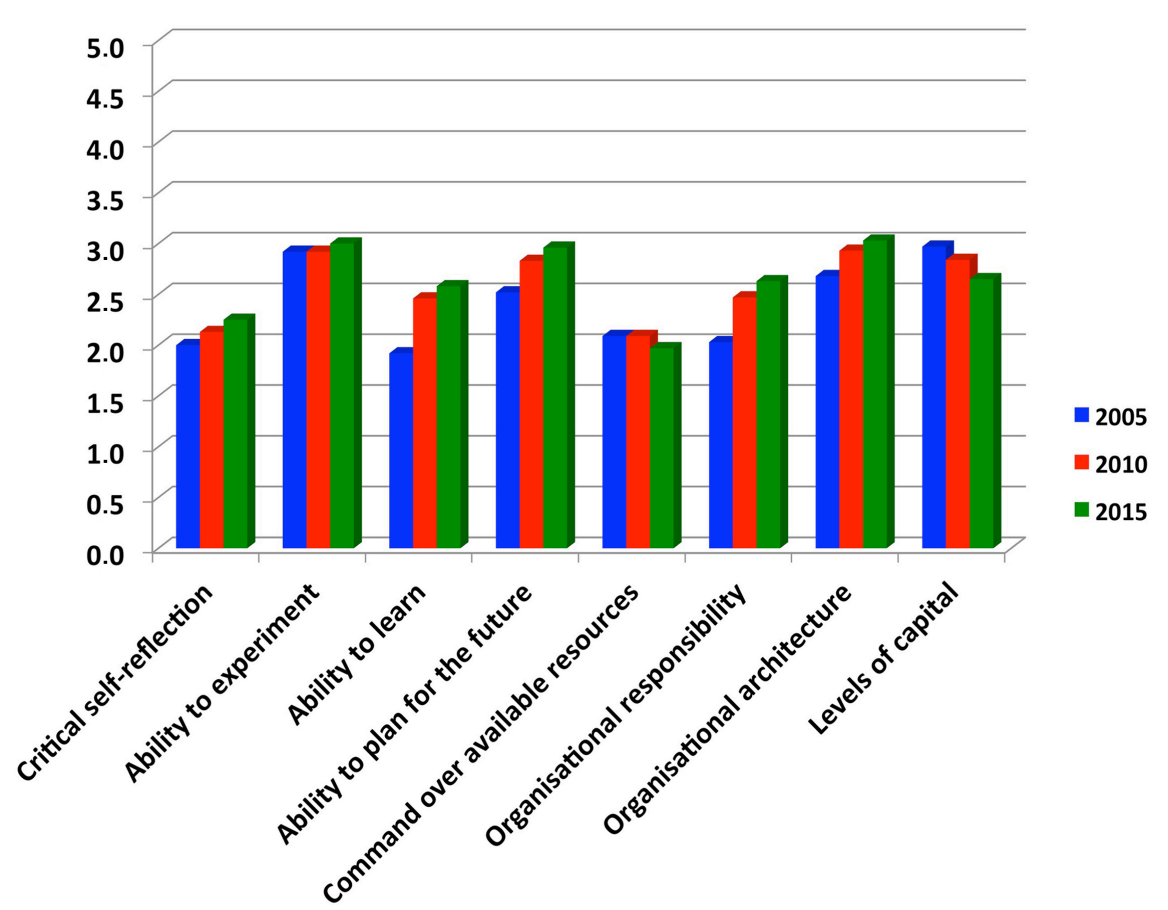

Figure 4. Summary of results of ACI analysis for Selsey, UK.

changing management responsibilities, shifts in political ideology and social contracts. A decline in the ACI in a category was attributed to a decrease in available resources, the inability to control existing resources and to austerity 
Adaptive Capacity Index (ACI) Sub-Components Scores: Brower County, US

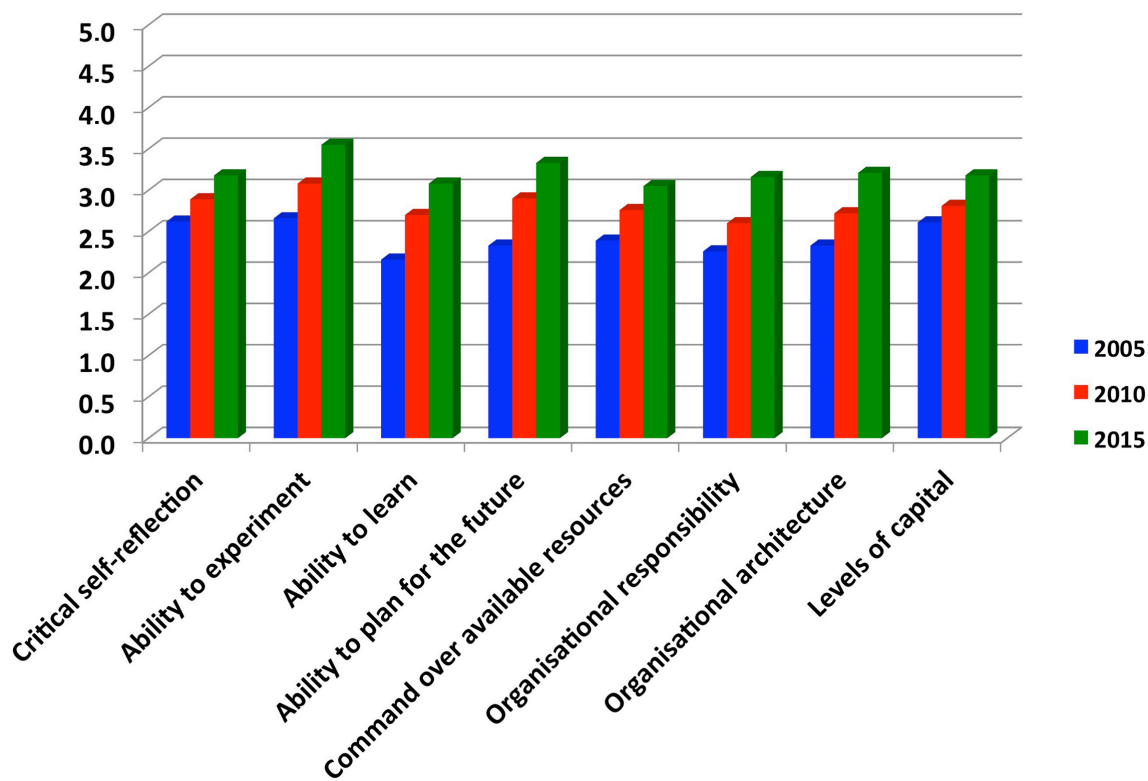

Figure 5. Summary of results of ACI analysis for Broward county, US.

Adaptive Capacity Index (ACI) Sub-Components Scores: Santos, Brazil

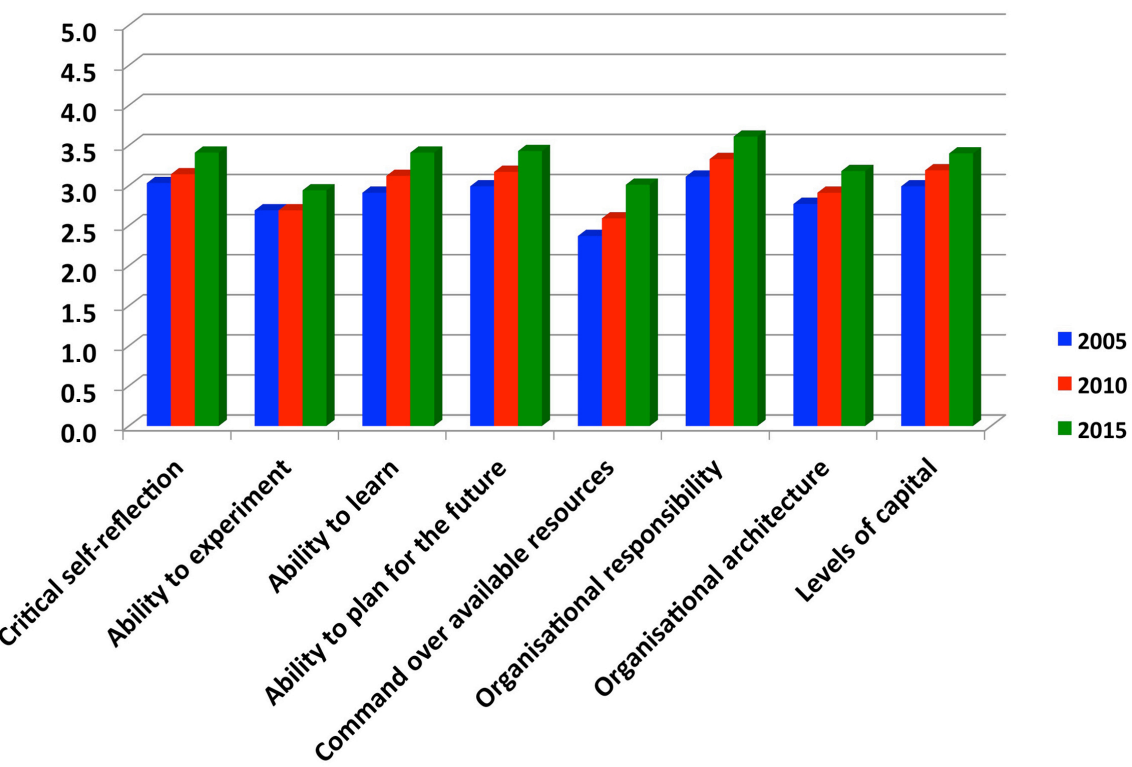

Figure 6. Summary of results of ACI analysis for Santos, Brazil.

measures that have been in place and enforced at a national level. A positive trend was observed in the ability to learn and to plan for the future, suggesting that collaborative action between organizations increased in the 2005-2015 timeframe. Respondents pointed to the importance of partnership funding and co-funding mechanisms now required for capital projects as a catalyst for closer working relationships between the different levels of government. It was also pointed out that the re-organization of the structures of major governmental 
agencies has provided greater interconnectedness between these agencies, promoting cross-learning and joint planning efforts.

Broward County shows a continuing and persistent positive progression in the various ACI factors over the 2005-2015 decade (Table 3). Respondents associated this trend primarily with the establishment of the South Florida Regional Climate Change Compact (herein forward the "Compact"). The Compact has allowed factors such as the ability to learn and the ability to plan for the future, to be developed within the local governance structures and in the community. The Compact has enabled focus on legislation and policy, which has propagated widely with positive effect among organizations, involved the establishment of key relationships in the region, and the ability to correct actions by analysis and observation of community impacts, was seen as the primary reasons for the consistent increase in adaptability scores over the decade.

In Santos, the ACI analysis showed some progression toward adaptability, but this was slow or stagnant in some factors (Table 3). Stagnation was seen by local actors as related to a lack of organizational integration across the risk management regime, and the dominance of the Civil Defense Department of the city in aspects of the city's adaptation agendas. Civil Defense seemed to suppress incentives for leadership and innovation across multiple agencies. Global economic pressures were also mentioned as a negative force in Santos. The current economic and political turbulence in Brazil might constrain resources and funding opportunities for combating the effects of sea-level rise. Experience from previous recessions shows that economic downturn has a detrimental effect on getting resources to environment issues in the country because resources to cope with economic recession might be considered more urgent, with climate change initiatives neglected. But recent severe storm surges in the city (April, August and October 2016), which affected the study area harshly, might contribute to keeping adaptation actions on the political agenda.

\section{Conclusions}

In this study we investigated how three coastal communities might consider actions for adaptation to climate change, taking into account geographical information, social factors and risk perceptions. These factors influence community resiliency and planning processes to cope with coastal flooding due to SLR, for example. METROPOLE investigated the collaborative processes of different communities in addressing risks to local ecological resources, infrastructure and quality of life, due to hazards derived from larger-scale forces, like sea level rise. This project focused on the processes that shape adaptation of three coastal communities in three countries. It worked jointly with these communities in defining the problem, examining risks, and understanding the benefits and obstacles that may hinder implementation of adaptation options. The project participants co-designed methods to quantify vulnerability of coastal real estate, evaluated benefits and costs of adaptation options, quantified social attitudes about the implementation of these options, and explored methods of engaging 
the community.

The case studies of Broward County (USA) and Santos (Brazil) show that there are choices for increasing resiliency against sea level rise that have a high benefit-cost ratio. Specifically, these communities found that fortification of the coast, elevation of real estate and flood proofing are important investments that help mitigate higher costs due to flood risks 60 - 100 years from now.

Based on the surveys' results, there is a clear sense from each community of the risk of floods due to intense storms and of the benefits of engaging as a community early in a process that helps people to understand risks, impacts and costs. A majority of workshop participants prioritized pursuing physical infrastructure and green infrastructure actions now or within the coming years or decades. This will have benefits that include a social and natural science basis and that address the local and regional social, political and cultural context. Assessment of the risks due to exposure and sensitivity of coastal communities to coastal flooding is essential for informing decision-making. Strategies to promote public understanding and awareness of the tangible effects of climate change are fundamental in developing policy options. The multidisciplinary, multinational nature of METROPOLE was important in providing local governments with scientific evidence of the need for adaptation to SLR. At the core of the analysis are estimates of economic costs of the impact of floods on urban real estate under SLR for middle- and long-term 21st century projections.

Other lessons of the METROPOLE project relate to technical challenges of conducting transnational and community-based adaptation research. The COAST software was designed in the US and uses data that are readily available there for almost any coastal community (i.e., digital parcel maps; databases of real estate tax assessment values; building construction type and use; knowledge of sales ratios; actual market values; digital elevation models with high accuracy; previous flood studies; flood depth damage functions, etc.). It was initially assumed that substitutes for these inputs would be available elsewhere, but the experience with Santos and Selsey proved that realities are different.

The project had to tailor the assessment framework to each context. For example in the UK, tax assessment estimates of building value are only performed on residential properties and are for categories of buildings only, not for individual structures (therefore, commercial properties were not included in the analysis). Similarly, the US National Oceanic and Atmospheric Administration (NOAA) has developed consistent high-resolution LiDAR coverage of developed areas in all of the coastal US, but high-resolution LiDAR was difficult to find outside of the US. As a result, the lower-resolution imagery available in the UK did not recognize the existing seawall at Selsey. In Santos, the municipal contractor discovered that LiDAR tiles had been set at a variety of elevations without edge-matching, creating an unreliable mosaic. Corrections were made in each of these cases and others, but the patterns demonstrate the need for practitioners to maintain extreme flexibility, creativity and resourcefulness in conducting transnational research in adaptation to SLR and storm surge. 
A positive common aspect at the three sites was the commitment of the stakeholders in taking part in the process, evaluating which adaptation measures could be more effective in their cities. While in the US and UK structural solutions and voluntary buyouts were prioritized into the future, Brazil prioritized structural solutions and ecosystem restoration and not voluntary buyouts. However all three cities considered assessments and identification of local districts in vulnerable coastal areas. The ACI results illustrate barriers to adaptation actions, including technical, economical, and political. Future studies should design and implement a technical linkage between the COAST model and the ACI. Linking the ACI to evaluations conducted iteratively after implementing different COAST scenarios may help improve adaptation capacity.

METROPOLE was successful in that it galvanized interdisciplinary efforts among local actors in Selsey, Broward County and Santos, so that the cities can protect their buildings and population to cope with SLR consequent on climate change.

Categorizing the choices in coastal infrastructure for adaptation that are available to policy makers will allow for comparisons of their potential impacts on cities and ecosystems, and of their value in preparation for long-term SLR. We have not gone that far in gaining insight into the advantages and disadvantages of different coastal infrastructure types, and how they might be applied in a given environmental and land-use context. However, the adaptations selected by the three communities may trigger governance processes that in the end will have a lasting effect on these communities. In Santos, scientific insights from the METROPOLE project are being considered to formulate recommendations for planners on public finance options and time perceptions to promote adaptation planning. After the first workshop, the mayor of Santos created the Municipal Commission for Adaptation to Climate Change (Comissão Municipal de Adaptação à Mudança do Clima, Decree 7293 of 30 November 2015), which will seek to define areas that require flood protection and public education.

Nevertheless, as pointed out by the respondents of the ACI questionnaire, within the institutions the issue of adaptation is not being well conducted or even considered. Thus, the initial measures taken by the local government need to resonate in the key sectors of Santos, so that even in times of economic and political instability such as the present one, it can be recognized and internalized within organizations and the society as a whole, the urgency of adapting to the effects of sea level rise, as their consequences (like severe storm surges) are already in course, affecting Santos more strongly and more often.

\section{Acknowledgements}

This work was supported by the "Belmont Forum-G8 Initiative Collaborative Research: METROPOLE: An Integrated Framework to Analyze Local Decision Making and Adaptive Capacity to Large-Scale Environmental Change”, through the FAPESP-Sao Paulo State Research Foundation (2012/51876-0) and the US National Science Foundation (Grant No. NSF ICER-1342969). 


\section{References}

[1] UNDESA. United Nations, Department of Economic and Social Affairs, Population Division (2015) World Population Prospects: The 2015 Revision, Key Findings and Advance Tables. Working Paper No. ESA/P/WP.241.

[2] McGranahan, G., Balk, D. and Anderson, B. (2007) The Rising Tide: Assessing the Risks of Climate Change and Human Settlements in Low Elevation Coastal Zones. Environment and Urbanization, 19, 17-37. https://doi.org/10.1177/0956247807076960

[3] Seto, K.C., Fragkias, M., Güneralp, B. and Reilly, M.K. (2011) A Meta-Analysis of Global Urban Land Expansion. PLoS ONE, 6, e23777. http://journals.plos.org/plosone/article?id=10.1371/journal.pone.0023777 https://doi.org/10.1371/journal.pone.0023777

[4] Reguero, B.G., Losada, I.J., Diaz-Simal, P., Mendes, F.J. and Beck, M.W. (2015) Effects of Climate Change on Exposure to Coastal Flooding in Latin America and the Caribbean. PLoS ONE, 10, e0133409. https://doi.org/10.1371/journal.pone.0133409

[5] Magrin, G.O., Marengo, J.A., Boulanger, J.-P., Buckeridge, M.S., Castellanos, E., Poveda, G., Scarano, F.R. and Vicuña, S. (2014) Chap. 27. Central and South America. In: Climate Change 2014: Impacts, Adaptation, and Vulnerability, Cambridge University Press, Cambridge, UK and New York, 1499-1566.

[6] Rhein, M., Rintoul, S.R., Aoki, S., Campos, E., Chambers, D., Feely, R.A., Gulev, S., Johnson, G.C., Josey, S.A., Kostianoy, A., Mauritzen, C., Roemmich, D., Talley, L.D. and Wang, F. (2013) Observations: Ocean. In: Stocker, T.F., Qin, D., Plattner, G.-K., Tignor, M., Allen, S.K., Boschung, J., Nauels, A., Xia, Y., Bex, V. and Midgley, P.M., Eds., Climate Change 2013: The Physical Science Basis. Contribution of Working Group I to the Fifth Assessment Report of the Intergovernmental Panel on Climate Change, Cambridge University Press, Cambridge, UK and New York.

[7] Wong, P.P., Losada, I.J., Gattuso, J.P., Hinkel, J., Khattabi, A., McInnes, K.L., Saito, Y. and Sallenger, A. (2014) Coastal Systems and Low-Lying Areas. In: Field, C.B., Barros, V.R., Dokken, D.J., Mach, K.J., Mastrandrea, M.D., Bilir, T.E., Chatterjee, M., Ebi, K.L., Estrada, Y.O., Genova, R.C., Girma, B., Kissel, E.S., Levy, A.N., MacCracken, S., Mastrandrea, P.R. and White, L.L., Eds., Climate Change 2014: Impacts, Adaptation, and Vulnerability. Part A: Global and Sectoral Aspects. Contribution of Working Group II to the Fifth Assessment Report of the Intergovernmental Panel on Climate Change, Cambridge University Press, Cambridge, UK and New York, 361-409.

[8] ECLAC (2011) Efectos del Cambio Climático en la Costa de América Latina y el Caribe: Dinámicas, Tendencias y Variabilidad Climática [Effects of Climate Change on the Coast of Latin America and the Caribbean: Dynamics, Trends and Climate Variability]. LC/W.447, The Economic Commission for Latin America and the Caribbean (ECLAC), The Spanish Climate Change Office under the Ministry of Agriculture, Food and Environment of the Government of Spain, and the Environmental Hydraulics Institute of Cantabria University, ECLAC, Santiago de Chile, Chile, $263 \mathrm{p}$.

[9] GEI Consultants (2015) Final Report to the University of South Florida, COAST Modeling for Broward County, Florida, USA, for the Belmont Forum-GB Initiative Collaborative Research Initiative, METROPOLE: An Integrated Framework to Analyze Local Decision Making and Adaptive Capacity to Large-Scale Environmental Change. Portland, ME.

[10] GEI Consultants (2016) Final Report to the University of South Florida, COAST Modeling for Selsey, U.K., for the Belmont Forum-GB Initiative Collaborative Re- 
search Initiative, METROPOLE: An Integrated Framework to Analyze Local Decision Making and Adaptive Capacity to Large-Scale Environmental Change. Portland, ME.

[11] Ross, H., Shaw, S., Rissik, D., Cliffe, N., Chapman, A., Hounsell, V., Udy, J.N.T. and Schoeman, J.A (2015) Participatory Systems Approach to Understanding Climate Adaptation Needs. Climatic Change, 129, 27-42.

https://doi.org/10.1007/s10584-014-1318-6

[12] Georgeson, L., Maslin, M., Poessinouw, M. and Howard, S. (2016) Adaptation Responses to Climate Change Differ between Global Megacities. Nature Climate Change, 6, 584-588. https://doi.org/10.1038/nclimate2944

[13] Pelling, M., High, C., Dearing, J. and Smith, D. (2008). Shadow Spaces for Social Learning: A Relational Understanding of Adaptive Capacity to Climate Change within Organizations. Environment and Planning A, 40, 867-884.

https://doi.org/10.1068/a39148

[14] Pelling, M. and Manuel-Navarrete, D. (2011) From Resilience to Transformation: The Adaptive Cycle in Two Mexican Urban Centers. Ecology and Society, 16, 11. https://doi.org/10.5751/es-04038-160211

[15] Gasparro, M.R., Sousa, E.C.P.M., Giordano, F. and Argentino-Santos, R.C. (2008) Occupation History of the Santos Estuary, Perspectives on Integrated Coastal Zone Management in South America. In: Neves, R., Baretta, J.W. and Mateus, M., Eds., Perspectives on Integrated Coastal Zone Management in South America, IST, Rio de Janeiro, Brazil Press.

[16] Pelling, M. and Zaidi, R.Z. (2013) Measuring Adaptive Capacity: Application of an Indexing Methodology in Guyana. EPD Working Paper \#47, Department of Geography, King's College, London.

[17] Paterson, S.K., Pelling, M., Nunes, L.H., Moreira, F.A., Guida, K. and Marengo, J. (2017) The Scaled Asymmetries of Adaptive Capacity: In Florida, São Paulo and England. Geoforum, 81, 109-119.

[18] Catalysis Adaptation Partners (2015) Coastal Adaptation to Sea Level Rise Tool (COAST) Version 3.0. Catalysis Adaptation Partners, LLC, South Portland, ME, Licensed through GEI Consultants, Inc.

[19] Merrill, S., Sanford, R. and Lapping, M. (2008) Planners and Climate Change Action: An Approach for Communities. Maine Policy Review, 17, 142-152.

[20] Merrill, S., Kirshen, P., Yakovleff, D., Lloyd, S., Keeley, C. and Hill, B. (2012) COAST in Action: 2012 Projects from New Hampshire and Maine. New England Environmental Finance Center Series Report \#12-05. Portland, Maine.

[21] Kirshen, P., Merrill, S., Slovinsky, P. and Richardson, N. (2012) Simplified Method for Scenario-Based Risk Assessment Adaptation Planning in the Coastal Zone. Climatic Change, 113, 919-931. https://doi.org/10.1007/s10584-011-0379-Z

[22] Marengo, J.A., Nunes, L.H., Souza, C.R.G., Harari, J., Muller-Karger, F., Greco, R., Hosokawa, E.K., Tabuchi, E.K., Merril, S.B., Reynolds, C.J., Pelling, M., Alves, L.M., Aragão, L.E., Chou, S.C., Moreira, F., Paterson, S., Lockman, J.T. and Gray, A.G. (2017) A Globally-Deployable Strategy for Co-Development of Adaptation Preferences to Sea-Level Rise: The Public Participation Case of Santos, Brazil. Natural Hazards, 1-15. https://doi.org/10.1007/s11069-017-2855-x

[23] University of Florida GeoPlan Center (2014) Florida Digital Elevation Model (DEM) Mosaic-5 Meter Cell Size-Elevation Units Feet.

[24] NOAA National Oceanic and Atmospheric Administration (2014) Datums for 8722939, Ft. Lauderdale Bahia Yacht Club, FL. NOAA. 
http://tidesandcurrents.noaa.gov/datums.html?id $=8722939$

[25] Gulf Engineers \& Consultants (2006) Depth-Damage Relationships for Structures, Contents, and Vehicles and Content-to-Structure Value Ratios (CSVR) in Support of the Donaldsville to the Gulf, Louisiana, Feasibility Study. Prepared for US Army Corps of Engineers, New Orleans District, New Orleans, Louisiana.

[26] Stott, D., Boyd, D.S., Beck, A. and Cohn, A.G. (2015) Airborne LiDAR for the Detection of Archaeological Vegetation Marks Using Biomass as a Proxy. Remote Sensing, 7, 1594-1618. https://doi.org/10.3390/rs70201594

[27] Capita Symonds (2008) Strategic Flood Risk Assessment of Chichester District Council, Volume II, Technical Report.

[28] New Forest District Council (2010) North Solent Shoreline Management Plan.

[29] Daniels, S.E. and Walker, G.B. (2001) Working through Environmental Conflict: The Collaborative Learning Approach. Praeger Publishers, Westport, CT.

[30] Burch, S. (2010) Transforming Barriers into Enablers of Action on Climate Change: Insights from Three Municipal Case Studies in British Columbia, Canada. Global Environmental Change, 20, 287-297.

Submit or recommend next manuscript to SCIRP and we will provide best service for you:

Accepting pre-submission inquiries through Email, Facebook, LinkedIn, Twitter, etc. A wide selection of journals (inclusive of 9 subjects, more than 200 journals)

Providing 24-hour high-quality service

User-friendly online submission system

Fair and swift peer-review system

Efficient typesetting and proofreading procedure

Display of the result of downloads and visits, as well as the number of cited articles

Maximum dissemination of your research work

Submit your manuscript at: http://papersubmission.scirp.org/

Or contact ajcc@scirp.org 